\title{
Understanding Indonesia: the Role of Economic Nationalism ${ }^{1}$
}

\author{
Thee Kian Wie ${ }^{2}$ \\ Indonesian Institute of Sciences
}

\begin{abstract}
In this paper it is argued that economic nationalism in Indonesia, in its various manifestations, has been an important factor in determining particular economic policies since Indonesia's independence up to the present. These economic policies particularly related to the ownership of productive assets owned by foreigners or by residents considered to be 'foreign', particularly Dutch business interests before 1957 and the ethnic Chinese, including Sino-Indonesians, and to the economic functions performed by foreigners or by 'foreign' residents. Focusing on one factor alone to understand Indonesia, specifically Indonesia's economic policies over time, is necessarily arbitrary and subjective. However, looking at Indonesia's modern economic history since independence through the prism of economic nationalism does to an important degree explain or highlight the major considerations underlying particular economic policies of the Indonesian government because they reflected Indonesia's national aspirations or national interests.
\end{abstract}

\section{Introduction}

Offering an economic perspective to understand Indonesia is necessarily speculative. Such an effort does not require specifying a rigorous economic model in which a dependent variable, say a specific economic policy, is closely associated with one or more independent variables, perhaps the economic ideas held by the main economic policy-makers or the links these policy-makers have to big business.

1 I would like to acknowledge the valuable comments and suggestions of an anonymous referee. However, I alone am responsible for any errors and shortcomings of this paper.

2 Senior Economist, Economic Research Centre, Indonesian Institute of Sciences (P2E-LIPI), Jakarta.E-mail: theekw@cbn.net.id 
With these qualifications in mind, we venture to put forward one important factor, which in my view has to a large extent influenced Indonesia's economic policies and performance as well as the national psyche of the Indonesian people, namely economic nationalism. In this paper economic nationalism is broadly defined as nationalism as it affects or determines the economic policies of a particular country. Focusing on one factor alone to understand Indonesia, specifically Indonesia's economic policies over time, is necessarily arbitrary and subjective. However, looking at Indonesia's modern economic history since independence through the prism of economic nationalism does, to a greater or lesser extent, explain the considerations underlying particular economic policies of the Indonesian government.

\section{The Importance of Economic Nationalism}

A distinguished economics professor at the University of Chicago, the late professor Harry Johnson, defined economic nationalism as 'the national aspiration to acquiring and controlling property owned by foreigners and performing economic functions performed by foreigners' (Johnson, 1972: 26). This definition is particularly appropriate when trying to understand Indonesia's economic policies because the force of economic nationalism in Indonesia has been more intense, occasionally virulent, particularly during the early independence period in the 1950s. Though less strident at present, economic nationalism is to a certain extent still reflected in Indonesia's current economic policies.

During the 1950s, economic nationalism was primarily directed at the continuing economic dominance of Dutch and ethnic Chinese business interests. In the early $1990 \mathrm{~s}$, economic nationalism took the form of what I would call 'industrial nationalism' or 'technological nationalism', which is appropriate for an emerging great power as Indonesia is. This industrial nationalism was expressed by the aspiration to develop hightechnology industries. In the late 1990s, after the Asian financial crisis, economic nationalism was directed at the International Monetary Fund (IMF) for imposing its allegedly inappropriate economic recovery program on the Indonesian government. 


\section{Economic Nationalism During the 1950s}

\section{The continuing economic dominance of Dutch business}

Despite hopes on the part of Indonesians and Dutchmen alike that political relations between Indonesia and the Netherlands would improve after the transfer of sovereignty to Indonesia on 27 December 1949, as arranged at the Round Table Conference (RTC) in The Hague in the autumn of 1949, relations between the two countries continued to be prickly. Three contentious issues from the outset, one political and two economic, adversely affected relations between Indonesia and the Netherlands. The serious political issue concerned the steadfast refusal of the Netherlands to transfer West Irian (West New Guinea) to Indonesia on the grounds that Papuans were not Indonesians. But President Soekarno insisted that 'completing the national revolution' required the 'liberation of West Irian'. Soekarno's appeal was supported by the great majority of the Indonesian people because the Indonesian nationalists considered themselves the rightful inheritors of the whole territory of the Netherlands Indies.

The first economic issue that proved contentious was the demand by the Dutch delegation that Indonesia would have to take over the Netherlands Indies government's foreign debt to the Netherlands government, an amount equivalent to US\$1.13 billion, much of which constituted an internal component of approximately US\$800 million (three billion guilders) incurred as military expenses by the Netherlands to subdue the Indonesian Republic during Indonesia's war of independence. According to calculations by the Indonesian delegation, these military expenses amounted to about US\$320 million (Kahin, 1997).

Despite strenuous objections by Sumitro Djojohadikusumo, a member of the Indonesian delegation, the delegation eventually agreed to take over the Netherlands Indies debt because it expected generous financial assistance from the United States. This expectation was encouraged by Merle Cochran, the American representative at the RTC, who suggested that American aid would be generous. However, all the USA finally 
provided to Indonesia after the transfer of sovereignty was a paltry loan of US\$100 million by the US Export-Import Bank, a loan that had to be repaid with interest and was only a third the size of post-World War II US Export-Import Bank credits to the Netherlands (Kahin, 1997).

The second economic issue was the guarantee given by the Indonesian government that Dutch private companies would be allowed to continue operating in Indonesia without hindrance, just as they did during the Dutch colonial period. During Indonesia's war of independence (194549), several Dutch companies with operations in Indonesia had come to realise that the attempt to subdue the Indonesian republic by military force was futile. Intent on restarting their profitable businesses in Indonesia as soon as possible, these companies exerted great pressure on the Dutch government to extract guarantees from the Indonesian delegation at the Round Table Conference (RTC) in The Hague in late 1949 that their business interests could continue to operate without any hindrance in independent Indonesia (Meijer, 1994).

Perhaps because the Indonesian delegation wanted to secure a quick decision from the Dutch delegation to transfer sovereignty to Indonesia, the two delegations quickly reached an agreement on this issue, as contained in the Finec agreement (Financiele en Economische Overeenkomst [Financial and Economic Agreement]). This agreement secured maximum economic and financial benefits for the Netherlands, specifically the Dutch private companies operating in Indonesia. Finec included a clause that stated that nationalisation would only be permitted if it would be in Indonesia's national interest and if both parties agreed. A judge would then decide on the amount of compensation to be paid to the owners on the basis of the real value of the nationalised company. Finec also included an obligation for Indonesia to consult the Netherlands whenever its fiscal and monetary policies would affect Dutch economic interests in Indonesia (Meijer, 1994). No wonder that the late Professor Henri Baudet, a conservative Dutch economic historian from the University of Groningen, stated that Finec contained the maximum attainable guarantees for the unhindered continuation of the operations of Dutch companies in Indonesia (Baudet and Fennema, 
1983). On the other hand, the Indonesian government from the outset was saddled with a foreign debt burden unprecedented in the history of decolonisation (Lindblad, 2008).

The achievement of political independence without having economic independence was a serious problem for the Indonesian government. Not being able to exert much control over important segments of the economy, particularly the modern sectors of the economy (large estates, mining companies, large-scale industries, banking and wholesale trade) was a serious constraint for Indonesia's policy-makers. For instance, pursuing an independent monetary policy would be difficult if the Java Bank, the bank of circulation serving as the country's central bank, was still owned by the Dutch. Sutan Sjahrir, Indonesia's first prime minister during the war of independence, in 1951 expressed a widely held view when he stated that it was the continuing economic dominance of the Dutch, and not West Irian, that was the real fundamental problem bedevilling the relations between Indonesia and the Netherlands (Meijer, 1994).

Indonesia's frustration with the continuing economic dominance of the large Dutch enterprises was reflected in the 1952-53 annual report of Bank Indonesia, Indonesia's central bank. The report stated that only 19 per cent of capital in the non-agrarian sectors of the Indonesian economy was owned by Indonesians. The report also stated that in 1953, of the total transfer of profits overseas, Rp449 million (or 70 per cent of the total transfer) went to the Netherlands, and social transfers (for personal savings and pensions) of Rp464 million (or 83 per cent of the total) went to the Netherlands (Meijer, 1994).

Indonesia's economic dependence on the Netherlands or the Dutch companies was clearly indicated by the inter-island shipping industry, which was almost entirely monopolised by the Dutch-owned (Koninklijke Paketvaart Maatschappij [Royal Packet Company]). However, after Indonesia's independence, KPM's dominance of interisland shipping was gradually eroded. On 28 April 1952, to counter the dominance of KPM, the Wilopo cabinet established the state-owned, limited liability company Pelayaran Nasional Indonesia, PELNI, the 
IIndonesian national shipping company. Although KPM continued to be dominant in inter-island shipping, in the course of the 1950s, its dominant position was gradually being diminished. By 1956, one year before the Indonesian take-over of KPM, PELNI managed to carry 25 per cent of the cargo, which increased to 29 per cent in 1957 (Dick, 1987).

In the passenger trade, KPM was better able to retain its dominance with 94 per cent of the traffic. The introduction in 1956 of six new passenger ships enabled PELNI in 1957 to double the number of passengers it carried. For a company established only five years before, this was significant progress (Dick, 1987).

The above account shows that few, if any, of the newly-independent nations were left with a more crushing external financial burden and such severe restrictions on economic policy-making than those imposed on Indonesia by the provisions of the Finec agreement. The consequences were political instability resulting from sharp conflicts between moderate and radical leaders and a steadily deteriorating relationship with the Netherlands, which culminated, in the late 1950s, with the takeover and subsequent nationalisation of most of the remaining Dutch enterprises. As a consequence, Indonesia was only able to embark in earnest upon a path of independent economic development after 1966, seventeen years after the transfer of sovereignty (Thee, 2010).

\section{Measures to counter Dutch economic dominance and foster the growth of an indigenous Indonesian business class}

Like many other Indonesian nationalists, the economic policy-makers of the early independence period were strongly attracted to socialist ideals. These nationalists were averse to capitalism because it was associated with colonial rule. However, none of them, except for the communists, were attracted to Marxism-Leninism or other extreme leftist ideas. In fact, many nationalists interpreted 'socialism' as 'Indonesianisation' or 'indigenism', that is, breaking the control of foreign capital, mostly Dutch and ethnic Chinese, over the modern sectors of the economy, 
which, according to an estimate by Benjamin Higgins, a United Nations economic consultant to the Indonesian government in the 1950s, accounted for about 25 per cent of Indonesia's Gross Domestic Product (GDP) and about 10 per cent of total employment (Higgins, 1990). However, views differed about how this should be achieved, whether by nationalisation of these foreign-owned enterprises or by fostering a strong indigenous Indonesian business class (Mackie, 1971).

Despite their unhappiness with the continuing Dutch dominance over the economy, the major economic policy-makers during the early independence period were pragmatic men who, though attracted to socialist ideals, did not adhere to any rigid ideological doctrine (Booth, 1986). Through their writings, Hatta, Sumitro and Sjafruddin in particular, were quite influential on the formation of economic policymaking in the early independence period (Rice, 1983).

They were pragmatic politicians and realised that top priority had to be given to the country's economic stabilisation and rehabilitation. Higgins characterised this group as 'economics-minded' persons (Higgins, 1957). Because a large part of the modern export industries were still owned and operated by the Dutch, these policy-makers realised that they had, whether they liked it or not, to protect the legal rights of the Dutch enterprises. Hence, the Dutch enterprises were allowed to continue operating in Indonesia, although this was strongly opposed by more radical nationalists.

Despite the constraints imposed by the provisions of Finec, the pragmatic economic policy-makers were determined to match Indonesia's hardwon political independence with meaningful economic sovereignty, though they realised it would take a long time and much effort. Indonesian nationalists viewed their national revolution as incomplete until they had transformed the colonial economy they had inherited into a national economy owned and controlled by their own nationals (Golay et al., 1969).

Under the provisions of Finec, nationalisation of some economic institutions or enterprises was allowed, albeit with conditions attached, 
and the Indonesian government quickly took steps to nationalise key institutions and large enterprises. These included the nationalisation of the Java Bank in 1951, which was subsequently renamed Bank Indonesia. The nationalisation of the Java Bank proceeded relatively smoothly, because it was recognised that control of money and credit was an essential ingredient of sovereignty (Anspach, 1969).

Other measures to put key enterprises under national control included the transfer of domestic air transport from the Royal Netherlands Indies Airline (KNILM) to Garuda Indonesian Airways, Indonesia's new air transport company. The railways on Java and main public utilities were also put under control of the Indonesian government (Burger, 1975). The Central Trading Company (CTC), Indonesia's first government-owned trading company, established in Bukittinggi in 1947, was assigned by Vice-President Hatta to challenge the monopoly of the 'Big Five', the five large Dutch trading companies (Daud, 1999).

Since the early 1950s pressures for preferential treatment of indigenous Indonesian businessmen had also grown stronger. The first major program to develop a strong indigenous business class was the Benteng [Fortress] program, launched in April 1950 by Djuanda, then Minister of Welfare (Anspach, 1969). According to Sumitro, Minister of Trade and Industry in 1950-51, the purpose of the Benteng program was to set up a counter-force to Dutch economic interests (Sumitro, 1986). The Benteng program focused on securing national control of the import trade. Under this program, import licenses for restricted categories of easy-to-sell goods were reserved exclusively for indigenous Indonesian importers. The provisions of the program, however, did not specifically exclude ethnic Chinese businessmen who were Indonesian citizens (Mackie, 1971). In fact, however, the Benteng program was aimed at countering Chinese as well as Dutch economic interests. Countering the economic interests of ethnic Chinese businessmen was considered necessary because they continued to dominate the intermediate trade in the rural areas and the retail trade in the urban areas, just as in the colonial period. 
The Benteng program's focus on the import trade was based on the consideration that it was the most susceptible to state control through the allocation of import licenses. This sector was also considered the most suitable to promote indigenous businessmen, because it required relatively small amounts of capital and corporate resources compared with other economic activities, such as manufacturing. It was hoped that through this import trade, indigenous Indonesian entrepreneurs would be able to accumulate sufficient capital to move into other sectors (Robison, 1986: 44).

On paper, the requirements needed by prospective indigenous Indonesian importers to qualify for the allocation of import licenses were fairly stringent. In practice, however, the Benteng program led to considerable abuses because ethnic Chinese importers, excluded from the program, were able to acquire import licences. They learned to operate through puppets, indigenous Indonesian license holders, who were referred to as 'briefcase importers' (importir aktentas) (Sutter, 1959; Mackie, 1971). Instead of building a strong indigenous Indonesian business class, the Benteng program had fostered a class of socially unproductive rentseekers.

To its credit, the Indonesian government soon realised the adverse effects of the Benteng program and took steps to weed out bogus importers (Burger, 1975). Because the Benteng program had failed to achieve its stated purpose, the government eventually abandoned it (Anspach, 1969). Hence, the twin goals of reducing the control of import trade by the 'Big Five' Dutch general trading companies and of fostering the growth of a strong indigenous Indonesian business class were not achieved.

After the mid-1950s, relations between Indonesia and the Netherlands deteriorated rapidly because of the Dutch government's refusal to discuss the status of West Irian (now renamed Papua province). When the Indonesian government, in November 1957, failed to persuade the United Nations General Assembly to adopt a resolution calling on the Dutch government to cede West Irian to Indonesia, militant workers from leftwing trade unions took over KPM, the Dutch inter-island 
shipping company, a major symbol of Dutch economic dominance. This action, which took the government by surprise, was subsequently followed by similar take-overs of the other Dutch enterprises.

In February 1959, the formal take-over of all Dutch enterprises was legalised. Altogether, 179 Dutch enterprises were nationalised. The nationalised companies were turned into state-owned enterprises (Siahaan, 1996; Dick, 2002). Hence, in one sweep the powerful Dutch business presence, which had operated in Indonesia since the second half of the nineteenth century, was eliminated.

\section{Tackling the 'Chinese Problem'}

The take-over and subsequent nationalisation of all Dutch enterprises went a long way towards satisfying Indonesia's desire for economic nationalism, but it still faced the economic dominance of the ethnic Chinese, including the Sino-Indonesians, whodominated the intermediate trade, as distributors of consumer goods (including imported consumer goods) and as collectors (or purchasers) of the agricultural produce of the indigenous Indonesian farmers and as money-lenders as well. As money-lenders the ethnic Chinese were often accused of charging usurious interest rates.

Hence, aside from taking steps to counter Dutch economic dominance, the Indonesian government also took steps to reduce Chinese economic dominance by affirmative policies to promote indigenous Indonesian entrepreneurs. However, taking measures to curtail Chinese economic activities proved to be more difficult than eliminating Dutch economic interests. For one thing, the number of ethnic Chinese was much greater than the Dutch, and their economic activities in the rural areas were much more intertwined with the economic activities of the indigenous population. Moreover, the large number of ethnic Chinese also included Indonesian citizens as well as 'foreign Chinese', citizens of the People's Republic of China, and 'stateless' ethnic Chinese who were loyal to Taiwan. It was therefore quite difficult for the Indonesian government to take measures against all ethnic Chinese because this group also 
contained a large number of Sino-Indonesians, that is, Indonesians of Chinese descent. Having fought against Dutch colonialism and its implied racism, many Indonesian leaders found overly discriminatory policies against the ethnic Chinese distasteful (Coppel, 1983).

Aside from the above Benteng program, the Indonesian government also took other measures to curtail the economic activities of the ethnic Chinese.

\section{The ban on ownership of some sectors by foreign citizens}

As it had been during the Dutch colonial period, ethnic Chinese businessmen continued to own and control most of the rice mills in Indonesia. For instance, in 1952, no fewer than 138 of 154 rice mills in East Java were owned by Chinese businessmen (Anspach, 1969). In view of the important economic role of these rice mills, the Indonesian government issued a regulation in 1954, which stipulated that the Chinese owners of these rice mills had to transfer ownership of the mills to indigenous Indonesians by March 1955. The regulation decreed that no new licenses for operating rice mills would be issued to foreigners. However, because of the difficulties in implementing this regulation, the government still granted licences to foreign Chinese on an annual basis (Suryadinata, 1992).

Aside from rice mills, stevedoring, harbour transport and wharfage enterprises were also mostly owned by ethnic Chinese, including foreign Chinese and Sino-Indonesians. Similar to the treatment of Chinese ownership of rice mills, the government in 1954 issued a decree that all these maritime enterprises had to be transferred to indigenous Indonesians by 1956 . However, because of the difficulties in implementing this decree, the deadline had to be extended to June 1956 (Anspach, 1969).

\section{Government decree 10 of 1959}

After the nationalisation of all Dutch enterprises in 1959, the ethnic 
Chinese community emerged as the strongest element in the economy, aside from the government itself and its state-owned enterprises. In the rural areas the Chinese had since the Dutch colonial period acquired a strong economic position in retail trade, rice milling and rural finance (Mackie, 1971). Given this economic dominance, the steadily deteriorating economic conditions, and the general suspicion that the ethnic Chinese were not loyal citizens, it was not surprising that the ethnic Chinese would be the next target of government policy, particularly the large number of foreign Chinese who were either citizens of the People's Republic of China or 'stateless' Chinese loyal to Taiwan.

To this end, on 16 November 1959, the Indonesian government issued Government Decree 10 of 1959 (PP 10 of 1959), which stipulated that from 1 January 1960 all foreign nationals would be banned from rural trade and would have to transfer their business to Indonesian nationals (Suryadinata, 1992). The government hoped that much of the rural trade run by the foreign Chinese would be taken over by cooperatives and businesses owned and run by indigenous Indonesians.

Because neither the cooperatives nor indigenous businessmen had the skills and experience to replace the Chinese rural traders, the ban caused considerable economic disruption and hardship to the rural population it was supposed to help (Somers, 1964). As economic conditions steadily deteriorated in the early 1960s, and President Soekarno's and the army's attention were increasingly focused on reclaiming Irian Barat from the Dutch, implementation of Government Decree 10 of 1959 was temporarily suspended (Suryadinata, 1992). Although a resumption of the implementation of the decree did not take place, the decree was never officially rescinded.

\section{Economic Nationalism During Guided Democracy}

When the Constituent Assembly that was elected in 1955 failed to agree on the ideological basis of the country, specifically whether it should be the secular Pancasila or Islam, President Soekarno on 5 July issued 
a decree that disbanded the legally elected Parliament and Constituent Assembly and reinstated the Constitution of 1945. Under the 1945 Constitution the President was head of state and head of government. Supported by the army under Army Chief of Staff General AH Nasution and the ascendant Indonesian Communist Party (Partai Komunis Indonesia, PKI), President Soekarno ushered in the period (from 1959 to 1965) of Guided Democracy and Guided Economy.

Since the early 1960s, economic conditions had steadily deteriorated with hyperinflation increasing rapidly to around 100 per cent, and political developments took an increasingly radical turn. Although President Soekarno was strongly opposed to the establishment of the Malaysian federation, which he saw as a neocolonialist plot, Malaysia officially came into being as a new nation on 16 September 1963.

President Soekarno reacted with anger and launched the 'Crush Malaysia' campaign. Malaysia was supported by Britain, Australia and New Zealand as well as the USA, and Soekarno whipped up anti-Western sentiments that grew into a frenzy of xenophobia. As these anti-British and anti-American sentiments grew stronger, trade unions affiliated with the Indonesian Communist Party (PKI) and the Indonesian Nationalist Party (PNI) late in 1963 started taking over British and American enterprises, followed by the take-over of other Western enterprises, including Belgian enterprises. However, the Indonesian government was careful not to nationalise these companies, as it had done with the Dutch enterprises in 1959 because this would have required expensive compensation that the government could not afford.

When the strongly anti-communist New Order government came to power in 1967, it returned all the confiscated British, American and other Western enterprises to their former owners. However, the new government did not return the nationalised Dutch enterprises but instead paid compensation to the former Dutch owners. 


\section{Economic Nationalism During the Soeharto Era}

During the authoritarian rule of President Soeharto, Indonesia made rapid economic progress accompanied by a steady decline in absolute poverty from 40 per cent of the population to 11 per cent in 1996. As living standards of the people improved, the force of economic nationalism gradually weakened. Public demonstrations against foreign investment were banned, particularly after the anti-Japanese, so-called Malari riots of mid-January 1974.

\section{The anti-Japanese Malari riots of January 1974}

On 15 and 16 January 1974, a visit by Kakuei Tanaka, the then prime minister of Japan, precipitated the worst riots in Jakarta since the advent of the New Order government under Soeharto. During these Malari riots (from Malapetaka Januari, January disaster), students and poor urban youths burned about 800 Japanese cars and 100 buildings and looted many shops that had been selling Japanese products (Ricklefs, 1993).

Although the riots were caused ostensibly by the 'over-presence' of Japanese direct investment in Indonesia, a sentiment reinforced by the huge billboards in Jakarta advertising various Japanese products, economic factors were not the only issue, nor was criticism of Japan's perceived dominant role in the Indonesian economy the only economic issue (Grenville, 1974). In fact, over the previous few months there had been widespread criticism ranging from the perceived dominant role of foreign aid and foreign investment and the attendant loss of sovereignty to complaints that non-indigenous entrepreneurs (meaning ethnic Chinese) were receiving preferential treatment, for example, the disproportionate allocation of subsidised credit. (Grenville, 1974).

In response to these riots, the government clamped down harshly and by 17 January the riots had been suppressed by the military. Around 770 people were arrested, almost all of whom were released almost two years later. However, three student leaders were sentenced to longer prison terms upon doubtful evidence. Three newspapers and eight other 
publications accused or suspected of being responsible for inciting the riots were banned, and one editor was also arrested (Ricklefs, 1993).

The government also responded to the Malari affair by introducing more restrictive measures against foreign investment and more measures in favour of indigenous (pribumi) Indonesian businessmen. For instance, from 1974, new foreign direct investment could only enter Indonesia in the form of joint ventures with national businessmen or companies in which indigenous businessmen held majority equity and exercised majority management control (Thee, 1995). The restrictive rules governing foreign investment were only lifted in June 1994 when the government found it necessary to deregulate the economy in order to increase investment and raise economic growth (Thee, 2006).

\section{Economic policies against the ethnic Chinese during the Soeharto era}

During the initial period of the Soeharto era, strong anti-Chinese sentiments prevailed among senior army officers. These officers suspected Chinese sympathies, if not links, with the People's Republic of China because of its alleged involvement in the attempted coup of 30 September 1965, but pragmatic considerations gained the upper hand. Because of the New Order's key policy objective of pushing economic growth (Booth, 1998), it was soon realised that the Chinese were essential to achieve this goal. To meet this objective, it was necessary to lift various restrictions on the economic activities of the Chinese that had been introduced during the Soekarno era. Although the Chinese were given wide opportunities in business, their activities in other fields, such as politics and culture, were severely curtailed (Thee, 2006).

Despite the gloomy outlook for the Chinese, including the SinoIndonesians, at the beginning of the New Order, the government's priority of economic development opened various opportunities for the Chinese. With their long commercial experience, greater business acumen, better access to capital, managerial and technical skills, traditional business contacts with the Chinese business networks in the East Asian region, 
and in some instances with their mutually profitable joint ventures with the powerful, indigenous (pribumi) power holders, the Chinese were able to move into a wide range of economic activities, including largeestate agriculture, manufacturing, real estate and banking, and thus prosper to a much greater degree than during the Dutch colonial period and during the Soekarno era (Thee, 2006).

During the Soeharto era, particularly during the later years, several antiChinese riots also took place, though generally on a small scale, but they were always supressed for fear that they could adversely affect the economy. It was only during the power vacuum just before Soeharto resigned as president in May 1998, that horrific, anti-Chinese riots took place in Solo and Jakarta, including rapes of Chinese women.

\section{The two presidential decrees on government contracts}

When the government was enjoying the windfall revenues from the two oil booms in the 1970s and early 1980s, it decided to pursue another affirmative policy to promote indigenous Indonesian entrepreneurship. To this effect, it issued two presidential decrees; one in 1979, Keputusan Presiden 14 of 1979, and one in 1980, Keputusan Presiden 14a of 1980, which stipulated that government contracts of up to Rp20 million were solely reserved for entrepreneurs from the 'economically weak groups in society' (golongan ekonomi lemah), a euphemism to refer to the indigenous Indonesians as distinct from the 'economically strong groups in society', that is, the ethnic Chinese. For contracts up to Rp100 million, bids had to be awarded by tender, but preferential treatment would still be given to entrepreneurs from the 'economically weak groups in society' even if their tenders were up to 10 per cent higher than the others (Daroesman, 1981).

To qualify as an entrepreneur from the 'economically weak groups', at least 50 per cent of their company would have to be owned by indigenous entrepreneurs, and more than half the members of the board of management would have to be indigenous managers. In addition, the amount of capital and net assets of the company would have to be less 
than Rp25 million in the case of trade and related activities, or less than Rp100 million in the case of manufacturing and construction. Local cooperatives could also qualify as economic enterprises owned and run by members of the 'economically weak groups' (Daroesman, 1981). Unlike the unsuccessful Benteng program, the above two presidential decrees were more successful in nurturing a relatively large group of successful indigenous entrepreneurs, including businessmen of the Kodel group.

\section{The appeal to help cooperatives}

Increasingly concerned by the widespread discontent about the perceived economic gap between rich and poor and particularly between the ethnic Chinese minority and the indigenous majority, President Soeharto in March 1990 invited the heads of the leading business conglomerates, most of them owned and controlled by ethnic Chinese tycoons, to his Tapos cattle ranch near Bogor. Many of these conglomerates had grown rapidly during the Soeharto era because of the preferential treatment they had received from the government, notably in the allocation of large sums of subsidised credit, thanks to the personal and business relationships they had established with the indigenous power holders, particularly President Soeharto. The size of these conglomerates only became evident when they or their subsidiaries had gone public after the stock exchange boom in 1989 (Thee, 2006).

Soeharto used this meeting to reduce sensitivity about the visible role of the Chinese-owned conglomerates, and to portray himself as the defender of the 'little people' (wong cilik) (Elson, 2001). On national television, President Soeharto strongly appealed to the assembled business tycoons to help the development of the cooperatives, mostly owned by members of the 'economically weak groups', by transferring a quarter of their assets to cooperatives and by allowing the cooperatives to purchase shares in these private companies as a means of closing the gap between rich and poor. Equal sharing of the nation's wealth would be a constant theme in Soeharto's speeches through the 1990s (Elson, 2001). 
However, beyond some token steps on the part of the conglomerates to heed Soeharto's appeal, it was, as could be expected, quite unsuccessful in reducing the economic power of the conglomerates and in increasing the role and strength of the cooperatives. In the end it was the Asian financial and economic crisis that reduced the wealth and power of the conglomerates when they had to repay their large overseas debts and their debts to the Indonesian government after it had bailed out their failed banks.

\section{The emergence of Indonesia's industrial nationalism}

Like in other emerging economies, economic nationalism in Indonesia has continued to be an important factor in determining Indonesia's economic policies. Its forms and manifestations may change over time in response to new challenges and opportunities. Since the late 1980 s, economic nationalism, as a result of rapid economic growth and successful industrialisation, manifested itself as the aspiration to become a great industrial power through the establishment of a range of strategic industries, including high-technology industries, such as an aircraft industry.

Proponents of this industrial nationalism (sometimes referred to as technological nationalism) argue that a proud, developing country, such as Indonesia, with its abundant natural resources and large population should not remain content with just being a 'tailor' to the world market, exporting cheap, labour-intensive products, such as clothing and textiles. Instead, it was high time for Indonesia to develop 'strategic industries', particularly capital-intensive, high-technology industries. Professor BJ Habibie, Indonesia's State Minister for Research and Technology from 1978 up to 1998 and Indonesia's foremost proponent of this industrial nationalism, pointed out that developing state-owned, high-technology industries was imperative if Indonesia were to sustain the growth of its manufactured exports, which had become the major engine of economic growth since the late 1980s. According to Habibie, Indonesia could not continue relying on its comparative advantage in resource and labour- 
intensive manufacturing in the face of strong competition from lower wage countries, such as China, Vietnam, India and Bangladesh. Because capital-intensive, high-technology industries are quite intensive in their use of human skills and sophisticated industrial technologies, Indonesia in its Second Long-Term Development Plan (1994-2019) would have to make a much greater effort in human resource development and the development of industrial technological capabilities than it had done so far (Thee, 1994).

Although industrial nationalism appeared to be in the ascendancy in the early 1990s, economic realities, notably Indonesia's large foreign debt burden and the slowdown in non-oil exports, particularly manufactured exports, which had been the major engine of growth since 1993, forced the government to continue its prudent macroeconomic policies. In the end, the more pragmatic, but no less nationalistic, policy-makers prevailed and were able to assert the primacy of sound macroeconomic policies. In fact, developments after the Asian economic crisis and the much reduced fiscal capacity of the Indonesian government spelt the end of the high-technology aircraft industry, at least for the foreseeable future.

\section{Economic Nationalism in the Post-Soeharto Era}

The Asian economic crisis of 1997-98 hit Indonesia hard, shown by the fact that, although since the early 1990s economic growth averaged more than 7 per cent per annum, the economy contracted by an unprecedented 13.1 per cent in 1998. Although positive growth resumed in 1999, economic growth remained rather sluggish and never exceeded the pre-crisis growth of 7 per cent plus, even though in 2007 it reached a post-crisis high of 6.3 per cent.

The Indonesian financial crisis started through contagion from the Thai currency crisis, which happened in July 1997. When in early October 1997, as a result of speculative pressure, the rupiah steadily depreciated by 55 per cent, and the foreign exchange reserves had dwindled to US\$10.5 billion, Indonesia's Minister of Finance approached the 
International Monetary Fund (IMF) to obtain financial support, hoping that the IMF good housekeeping seal would restore confidence in the rupiah.

In return for a large standby loan from the IMF, the government in its Letter of Intent to the IMF pledged to implement a comprehensive reform program, involving sound macroeconomic policies; restructuring the weak financial sector, including the closure of insolvent financial institutions; and structural reforms (Djiwandono, 2000: 54).

Market confidence, however, was not restored when, in November 1997, the government, in accordance with the IMF program, closed 16 insolvent banks to show its determination to deal decisively with financially troubled banks. This measure, however, led to a loss of confidence in the whole banking system. To prevent a panicky bank run by the public, Bank Indonesia issued a huge amount of emergency credits - referred to as Bank Indonesia's Liquidity Support (Bantuan Likuiditas Bank Indonesia) - to ensure that the other banks did not collapse (World Bank, 1998: 1.4-1.6). The currency crisis was now aggravated by a serious banking crisis.

Not surprisingly, several critics faulted the IMF for what they considered the unnecessarily hasty closure of the 16 banks, which destabilised the whole financial system and subsequently led to the insolvency of the entire banking system (Ramli, 2003: 11). Several economists, Indonesian and foreign, faulted President Soeharto for not faithfully implementing the comprehensive reform program agreed with the IMF. Other Indonesian economists, including Rizal Ramli and Kwik Kian Gie, severely criticised the IMF for imposing its reform program on Indonesia; they asserted that the reform program was not only overloaded, as reflected by its suggested structural reforms that had nothing to do with the currency crisis, but it was also inappropriate, as reflected by its imposition of tight fiscal policy, even though the government budget showed a surplus, unlike most of the Latin American countries that suffered a budget deficit. 
According to an evaluation report by the IMF, published in 2003, the single greatest cause of the failure of the November 1997 program was the lack of a comprehensive bank restructuring strategy, which led to a rapid expansion of liquidity to support weak banks. The resulting loss of monetary control in turn contributed to a weaker exchange rate and greater distress in the corporate sector (IMF, 2003: 1-2). The crisis became intensely political when President Soeharto fell ill in early December, making crisis management even more difficult. In early January 1998, the IMF negotiated a revised program, which focused heavily on structural conditionality, to signal a clean break with the past and restore confidence. The program failed to do so because of the visible lack of political commitment on the part of President Soeharto to the policies promised and partly because of the failure to address the critical banking and corporate debt problems. However, the IMF's evaluation in 2003 suggests that its own response to the program's failure had been inadequate in many respects (IMF, 2003: 2).

Mounting public criticism of the intrusive nature of perceived IMF meddling in Indonesia's internal affairs led the Indonesian government to exit the IMF program by the end of 2003. Instead, the Indonesian government issued a White Paper outlining the government's own recovery program, which turned out to be credible and subsequently led to increased growth, reaching a post-crisis growth of 6.3 per cent in 2007. In 2007, the government dissolved the Consultative Group on Indonesia (CGI), the aid consortium coordinated by the World Bank, stating that it would henceforth take full ownership of its development program. To the extent it needed foreign aid, it would discuss this directly with the individual donor countries, and not through the CGI.

\section{Conclusion}

In the previous pages, episodes of Indonesia's modern economic history, specifically the government's economic policies, have been described through the lens of economic nationalism. It was argued that economic nationalism, in its various manifestations, has been an important factor in 
determining these policies. In the case of the take-over and nationalisation of Dutch enterprises and the affirmative policies to promote indigenous Indonesian entrepreneurship, economic nationalism was directed at foreigners or Indonesian residents deemed foreign; for instance, the ethnic Chinese, in order to gain greater ownership and control over its productive assets by indigenous Indonesian entrepreneurs or stateowned enterprises.

In the case of industrial nationalism, the idea was essentially ambitious and forward-looking but inappropriate in view of the high opportunity costs required to develop high-technology industries and the lack of highly-trained technical personnel. Instead of developing these expensive industries, the government should have focused its efforts on strengthening and upgrading the labour-intensive industries that are required to generate employment for Indonesia's large labour force, and only gradually developed its skill-intensive, high-technology industries in line with the development of highly-trained manpower, which takes time.

From the controversy surrounding the role of the IMF in helping the Indonesian government, the government as well as the IMF gained valuable experience from the mistakes. For Indonesian policy-makers the experience they gained from handling the fall-out from the Asian financial crisis proved to be valuable when they skilfully dealt with the adverse effects of the Global Financial Crisis of 2008 by sticking to sound macroeconomic policies, while injecting a fiscal stimulus to keep the economy growing.

Under the pragmatic government of President Susilo Bambang Yudhoyono, the force of economic nationalism is being channelled in a more constructive direction that emphasises the role of Indonesia as a responsible and constructive member of the international community. As a member state of ASEAN, of the Asia-Pacific Economic Cooperation (APEC) and of the multilateral World Trade Organisation (WTO), and a signatory to the ASEAN-China Free Trade Agreement (ACFTA), the Indonesian government has clearly stated its intention to meet faithfully its regional and international commitments. 
However, the force of economic nationalism, more subdued and moderate now than during the Soekarno period, is in some respects still evident, as reflected by, for instance, the new Investment Law of 2007. Although the new law now provides equal legal status and treatment to domestic and foreign investors (World Bank, 2007: 21), its negative list contains a long list of fields in which foreign direct investment is either banned or subject to various equity restrictions. Aside from Indonesia's perceived unfavourable investment climate, this negative list has also deterred several potential foreign investors from investing in Indonesia.

\section{References}

Anspach, Ralph. (1969). 'Indonesia'. In Frank Golay, Ralph Anspach, M Ruth Pfanner and Eliezer B Ayal. (1969). Underdevelopment and economic nationalism in Southeast Asia. Ithaca and London: Cornell University Press. pp. 111-201.

Baudet, H and M Fennema. (1983). Het Nederlands belang bij Indie. Utrecht: Aula.

Booth, Anne. (1998). The Indonesian economy in the nineteenth and twentieth centuries: a history of missed opportunities. London: Macmillan Press.

Coppel, Charles A. (1983). Indonesian Chinese in crisis. Kuala Lumpur: Oxford University Press.

Dick, Howard W. (1987). The Indonesian inter-island shipping industry: an analysis of competition and regulation. Singapore: ASEAN Economic Research Unit, Institute of Southeast Asian Studies.

Djojohadikusumo, Sumitro. (1986). 'Recollections of my career'. Bulletin of Indonesian economic studies. 22(3): 27-39.

Djiwandono, J Soedradjad. (2000). 'Bank Indonesia and the Recent Crisis'. Bulletin of Indonesian economic studies. 36(1), April: 47-72.

Glassburner, Bruce (ed.). (1971). The economy of Indonesia: selected readings. Ithaca and London: Cornell University Press.

Golay, Frank, Ralph Anspach, M Ruth Pfanner and Eliezer B Ayal. (1969). Underdevelopment and economic nationalism in Southeast Asia. Ithaca and London: Cornell University Press.

Grenville, Stephen. (1974). 'Survey of Recent Developments'. Bulletin of Indonesian economic studies. 10(1), April: 1-32.

Higgins, Benjamin. 1957. Indonesia's economic stabilisation and development. New York: Institute of Pacific Relations.

Johnson, Harry. (1972). 'The ideology of economic policy in new states'. In (ed.) David Wall. Chicago essays in economic development. Chicago: University of Chicago Press. pp. 23-40. 
Kahin, GMcT. (1997). 'Some recollections from and reflections on the Indonesian revolution'. In (ed.) Abdullah Taufik. (1997). The heartbeat of the Indonesian revolution. Jakarta: PT Gramedia Pustaka Utama. pp. 10-27.

Lindblad, J Thomas. (2008). Bridges to new business: the economic decolonization of Indonesia. Leiden: KITLV Press.

Mackie, JAC. (1971). 'The Indonesian economy, 1950-63'. In (ed.) Bruce Glassburner. The economy of Indonesia: selected readings. Ithaca and London: Cornell University Press. pp. 16-69.

Meijer, Hans. (1994). Den Haag-Jakarta; de Nederlands-Indonesische betrekkingen 1950-1962 [Den Haag-Jakarta; Netherlands-Indonesia relations 1950-1962]. Utrecht: Aula.

Ricklefs, MC. (1993). A history of modern Indonesia since c. 1300, 2nd edn. London: Macmillan Press.

Ramli, Rizal. (2003). 'Life after the IMF'. Van Zorge report. 21 April 2003: 10-18.

Robison, Richard. (1986). Indonesia: the rise of capital. Sydney: Allen and Unwin.

Siahaan, Bisuk. (1996). Industrialisasi di Indonesia: sejak hutang kehormatan sampai banting stir [Industrialisation in Indonesia: from the debt of honour until the turnaround]. Jakarta: Pustaka Data.

Somers Heidhues, Mary. (1964). Peranakan Chinese politics in Indonesia. Ithaca: Interim Report Series, Modern Indonesia Project, Cornell University.

Suhadi Mangkusuwondo. (1967). 'Industrialization efforts in Indonesia: the role of agriculture and foreign trade in the development of the industrial sector'. $\mathrm{PhD}$ thesis. Berkeley: University of California.

Suryadinata, Leo. (1992). Pribumi Indonesians, the Chinese minority and China. 3rd edn. Singapore: Heinemann Asia.

Suryadinata, Leo (ed.). (2006). Southeast Asia's Chinese businesses in an era of globalization: coping with the rise of China. Singapore: Institute of Southeast Asian Studies.

Sutter, John. (1959). Indonesianisasi: a historical survey of the role of politics in the institutions of a changing economy, from the second world war to the end of the general elections (1940-1955). PhD thesis. Ithaca, Cornell University.

Taufik, Abdullah (ed.). (1997). The heartbeat of the Indonesian revolution. Jakarta: PT Gramedia Pustaka Utama.

Thee, Kian Wie. (1994). Reflections on Indonesia's emerging industrial nationalism. Working Paper no. 1. Perth: Asia Research Centre, Murdoch University. (1995). Government business relations in Indonesia in historical perspective. Unpublished manuscript. Jakarta.

. (2005). 'Indonesia's first affirmative policy: the 'Benteng' program in the 1950s'. Lembaran sejarah [History papers]. 8(3): 33-46.

(2006). 'The Indonesian government's economic policies towards the ethnic Chinese: beyond economic nationalism?' In (ed.) Leo Suryadinata. Southeast 
Asia's Chinese businesses in an era of globalization: coping with the rise of China. Singapore: Institute of Southeast Asian Studies.

. (2010). 'The debate on economic policy in newly-independent Indonesia: the debate between Sjafruddin Prawiranegara and Sumitro Djojohadikusumo. Itinerario. March 2010.

Wall, David (ed.). (1972) Chicago essays in economic development. Chicago: University of Chicago Press.

World Bank. (1998). Indonesia in crisis: a macroeconomic update, Jakarta, July 1998.

-------. (2007). Indonesia: economic and social update, April 2007. 